\title{
ELECTROPHORETIC COMPARISON OF SYRIAN AND CHINESE HAMSTER SPECIES
}

\author{
F. CSAIKL \\ Institut für Tumorbiologie/ Krebsforschung der Universität Wien, Borschkegasse 8a, A-1090 \\ Wien, Austria
}

Received 7.vii.83

\section{SUMMARY}

Twenty-six genetic loci were tested in Syrian and Chinese hamster species to investigate the genetic constitution of each species. Electrophoretic variability is reported and implications for genetic drift and phylogenetic relationship are discussed.

\section{INTRODUCTION}

Laboratory animals besides inbred strains of mice and rats are becoming more and more important for various biochemical and medical investigations.

Among an increasing number of species, the Syrian hamster Mesocricetus auratus, and the Chinese hamster, Mesocricetulus griseus, are two of the most widely used. Investigators working with this species mostly have to refer to small breeding groups. Because of a probably colony specific genetic drift it can be hazardous to compare certain biochemical results without the knowledge of the genetic constitution of the breeding group.

It was the aim of this study to elucidate both the genetic composition of our breeding groups and to investigate approximately the grade of heterozygosity of these two species. For that the study of the variation of alleles at polymorphic loci is among the best and one of the most widely used methods (Krog, 1976). Therefore we have used both starch and acrylamide gel electrophoresis techniques to screen the breeding groups in our laboratory.

\section{MAterial AND METHOdS}

The two hamster species investigated were randomly bred in small groups in our own laboratory. Brother-sister matings were avoided. Skeletal muscle was used as source of enzymes because the more usual organs heart, liver and kidney were used for preparation of DNA. These investigations will be published elsewhere. Preparation of samples and electrophoretic procedures were done according to established methods (Csaikl et al., 1980, Harris and Hopkinson 1976).

For Aminoacylase 1 (ACY-1) and unspecific muscle proteins (MP) two additional buffer systems were used:

(a) gel: 13 per cent starch in $0.005 \mathrm{M}$ Tris- $0.005 \mathrm{M} \mathrm{NaH}_{2} \mathrm{PO}_{4}$, $\mathrm{pH}=7.4$; bridge: $0.1 \mathrm{M}$ Tris $-0.1 \mathrm{M} \mathrm{NaH}_{2} \mathrm{PO}_{4}, \mathrm{pH}=7.4$; for Aminoacylase 1. This gel gave a better resolution than the cellogel electrophoresis described by Qavi and Kit (1980). 


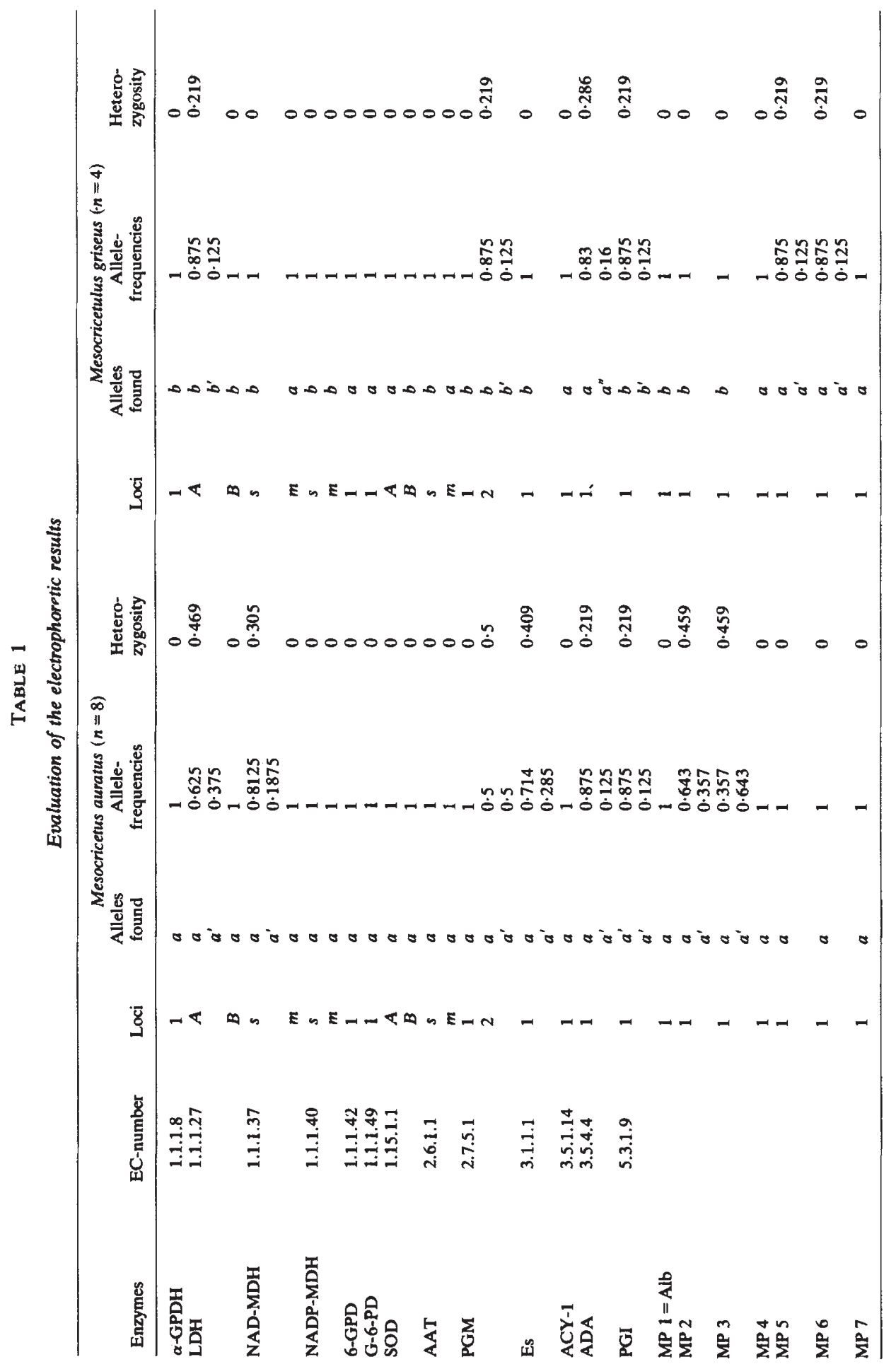


The gel was stained according to the method developed by the same authors.

(b) gel: discontinuous 7.5 per cent acrylamide, $\mathrm{pH}=8.9$ according to Maurer (1971), gel system No. 1; for unspecific muscle proteins.

With this method seven different protein fractions were detected and designated MP 1 to MP 7 starting with Albumin (Alb = MP 1). Acrylamide gels were stained in a solution containing 1 per cent Amido Black and 7 per cent acetic acid for $20 \mathrm{~min}$ and destained in 7 per cent acetic acid for several hours.

Both horizontally run starch gels and vertically run acrylamide gels were run at $10 \mathrm{~V} / \mathrm{cm}$ for 6 hours using cooling plates to avoid heating of the gels.

\section{Results AND Discussion}

The electrophoretic results are summarised in table 1. Although the two studied species were bred only in small groups a relatively large rate of heterozygosity was preserved. The Syrian hamster population is polymorphic at 30 per cent, the Chinese population at 26 per cent of the loci under investigation. This high degree of heterozygosity in our breeding colonies leads to the conclusion that these species are highly polymorphic in natural populations too. Therefore it is quite possible that in random bred colonies founder effects and uncontrolled resultant genetic drift results in numerous "sub-lines".

Several strong hints for this suggestion come from contradictory studies on the genome organisation of this species. Moyzis et al., (1977) described in the Syrian hamster a long period interspersion pattern while other authors (Ginatulina et al., 1980, Lelpold et al., 1982) found a short period interspersion pattern.

Different results on the mitochondrial genome organisation of the Syrian hamster (Nass, 1981; Csaikl, in preparation) support this suggestion too.

The large phylogenetic difference between these two species is shown both in the proportion of loci completely different for their alleles and in the values of the genetic distance calculated according to Nei (1975). The Syrian hamsters differ from the Chinese hamsters in the electrophoretic mobility of 15 from 26 gene products (that means 57.7 per cent). With respect to one enzyme (NADP-MDH) extremely large evolutionary divergence must have occurred, because the $s$-form in the Syrian hamsters moves more anodally than the $m$-form, while in the other species it was exactly the opposite. The same condition is known when comparing man and mouse NAPD-MDH's (Harris and Hopkinson 1977).

From the 26 loci, Nei's coefficient of the overall genetic distance $D=-\ln I$ was calculated (Nei 1975). The results of this study show a distance value of $D=1.57$ which places these species on the level of different genera if compared with other animals studied (for a review see Ayala, 1975; Avise, 1976 and Nei, 1975). This is in good agreement with the usual classification of these species as members of different genera based on morphological criteria (Walker, 1975). 


\section{REFERENCES}

AVISE, J. C. 1976. Genetic differentiation during speciation. In Ayala, F. J. (ed.) Molecular Evolution, Sinauer Associates, Sunderland, Mass, pp. 106-122.

AYALA, F. F. 1975. Genetic differentiation during speciation. In Dobzhansky, T., Hecht, M. A. and Steere, W. G. (eds.) Evolutionary Biology, vol. 8, Plenum Press, New York, London, pp. 1-75.

CSAIKL, F., ENGEL, W. AND SCHMIDTKE, J. 1980. On the biochemical systematics of three Apodemus species. Comp. Biochem. Physiol., 65B, 411-414.

GinATUlinA, L. K., GiNATUlinA, A. A. AND voronTSOV, N. N. 1980. The molecular structure of the mammalian genome. Genetica, 52/53, 127-138.

HARRIS, H. AND HOPKINSON, D. A. 1976. Handbook of Enzyme Electrophoresis in Human Genetics. North-Holland, Amsterdam.

KROG, H. H. 1976. Identification of inbred strains of mice, Mus musculus. I. Genetic control of inbred strains of mice using starch gel electrophoresis. Biochem. Genet., 14, 319-326.

LEIPOLD, M., ECKHARDT, R. AND SCHMID, M. 1982. Comparative DNA/DNA reassociation kinetics in three Hamster species. Comp. Biochem. Physiol., Vol. 72B, 385-391.

MAURER, H. H. 1971. Disc. Electrophoresis. de Gruyter, Berlin, New York.

MOYZIS, R. K., BONNETT, J. AND TS'O, P. O. P. 1977. DNA sequence organization of the Syrian hamster, J. Cell. Biol., 75, $120 a$.

NASS, M. M. K. 1981. Restriction endonuclease analysis of mitochondrial DNA from virustransformed, tumour and control cells of Human, Hamster and Avian origin. Biochim. Biophys. Acta, 655, 210-220.

NEI, M. 1975. Molecular Population Genetics and Evolution. North-Holland, Amsterdam.

QAVI, H. AND KIT, S. 1980. Electrophoretic patterns of Aminocylase-1 (ACY-1) isozymes for detecting ACY-1 activity. Biochem. Genet., 18, 669-679.

WALKER, E. P. 1975. Mammals of the World, J. Hopkins University Press, Baltimore, London. 